\title{
Correction to: Comparison of the Resistance to Cavitation Erosion and Slurry Erosion of Four Kinds of Surface Modification on 13-4 Ca6NM Hydro-Machinery Steel
}

\author{
C.V. Roa, J.A. Valdes, F. Larrahondo, S.A. Rodríguez, and J.J. Coronado (D)
}

Published online: 22 June 2021

\section{Correction to:}

\section{JMEPEG}

https://doi.org/10.1007/s11665-021-05908-9

In the originally published article, the panels in Figure 15 were labeled incorrectly. The article has been updated to ensure that the labels in the figure match the description in the article text.
Publisher's Note Springer Nature remains neutral with regard to jurisdictional claims in published maps and institutional affiliations.

The original article can be found online at https://doi.org/10.1007/ s11665-021-05908-9.

C.V. Roa, Research Group of Fatigue and Surfaces, School of Mechanical Engineering, Universidad del Valle, Cali, Colombia; and Universidad Autónoma de Occidente, Cali, Colombia; J.A. Valdes, S.A. Rodríguez, and J.J. Coronado, Research Group of Fatigue and Surfaces, School of Mechanical Engineering, Universidad del Valle, Cali, Colombia; and F. Larrahondo, EPSA E.S.P. A CELSIA Company, Cali, Colombia. Contact e-mail: john.coronado@correounivalle.edu.co. 